\title{
Tectonic characterization of North Indian continental margin: \\ Constraints from the geochemical and SHRIMP U-Pb zircon geochronological analysis of Wangtu Gneissic Complex (WGC), Lesser Himalaya-Higher Himalaya interface HIFZURRAHMAN $^{* 1}$, P NASIPURI ${ }^{1}$
}

${ }^{1}$ Indian Institute of Science Education and Research-Bhopal (* correspondence: hifzurrahman17@iiserb.ac.in, pritam@iiserb.ac.in)

A part of Paleoproterozoic granite-gneiss complex, commonly known as Wangtu Gneissic Complex (WGC), is exposed in the Wangtu-Karcham-Akpa region along the Sutlej valley, Northwest Himalaya, Himachal Pradesh. In the central part of WGC, the dominant rock type is granite, that grade to granite-gneiss towards the tectonic contacts with Higher Himalaya.

K-feldspar $\square-$ plagioclase $\quad\left(\mathrm{X}_{\mathrm{An}}=0.3-0.25\right) \quad \square-$ biotite $\left(\mathrm{X}_{\mathrm{Mg}}=0.35-0.45\right)-$ muscovite \pm hornblende constitutes the WGC. In most of the samples, the $\mathrm{SiO}_{2}$ and $\mathrm{Al}_{2} \mathrm{O}_{3}$ content varies between $69-74 \mathrm{wt} \%$ and $13-16 \mathrm{wt} \%$, respectively. The $\mathrm{CaO}, \mathrm{Na}_{2} \mathrm{O}$, and $\mathrm{K}_{2} \mathrm{O}$ vary between $0-2$ wt. $\%, 1-3 \mathrm{wt} \%$, 4-7 wt.\% respectively, and are classified as peraluminous granite. The low $\mathrm{CaO}$ content, in contrast to the relatively higher $\mathrm{K}_{2} \mathrm{O} / \mathrm{Na}_{2} \mathrm{O}$ (2.21 to 4.5 wt. \%) content, enrichment of $\mathrm{K}, \mathrm{Rb}$, $\mathrm{Ba}, \mathrm{Sr}$, Th, and $\mathrm{U}$ imply sediment sources for these granites. NCKFMASH phase topology, coupled with isopleth thermobarometry, implies K-feldspar - plagioclase - biotite stabilized at temperature $550-600^{\circ} \mathrm{C}$, pressure $0.6-0.8 \mathrm{GPa}$. A nearly similar temperature, i.e., $550-600^{\circ} \mathrm{C}$, is obtained by using the empirical formulation involving $\mathrm{Ti}$ solubility in biotite. Around 150-300 $\mu \mathrm{m}$-sized euhedral to subhedral magmatic zircons (aspect ratio from 2:1 to 4:1) occur as inclusion within the K-feldspar and plagioclase grains.

Zircons are oscillatory zoned. The U-Pb upper intercept ages from the marginal part concentrate between 1800-1900 Ma. These obtained ages (1800 to $1900 \mathrm{Ma}$ ) from magmatic zircons implies, that the north Indian continental margin was an active subduction zone during the formation of Columbia supercontinent which leads to the generation of magma parental to WGC. The distinct zircon cores exhibit an upper $\mathrm{U}-\mathrm{Pb}$ intercept age of $2460 \pm 20 \mathrm{Ma}$, which may experience the recycling of older crust and Late NeoarcheanPaleoproterozoic sources. 